\title{
XLV. Reply to Mr. R. C. Taylor's Remarks on the hypothesis of Mr. Robberds on the former level of the German Ocean
}

J.W. Robberds Esq. Jun.

To cite this article: J.W. Robberds Esq. Jun. (1827) XLV. Reply to Mr. R. C. Taylor's Remarks on the hypothesis of Mr. Robberds on the former level of the German Ocean , Philosophical Magazine Series 2, 2:10, 271-285, DOI: 10.1080/14786442708674387

To link to this article: http://dx.doi.org/10.1080/14786442708674387

曲 Published online: 10 Jul 2009.

Submit your article to this journal \lceil

Џll Article views: 2

Q View related articles $₫$ 
the caustic is a logarithmic spiral similar to the refracting curve.

If in the equations we have thus deduced for the involute to the caustic by refraction, $(m)$ be made equal to unity, we shall at once determine the involute to the caustic by reflexion. Thus for rectangular coordinates, we have

$$
\begin{aligned}
& \mathrm{X}^{2}+\mathrm{Y}^{2}-2 \mathrm{X} x-2 \mathrm{Y} y=0 \ldots \ldots \ldots(\alpha) \\
& \mathrm{Y} y^{\prime}+\mathrm{X}=0 \ldots \ldots \ldots \ldots \ldots \ldots(\beta)
\end{aligned}
$$

$\mathrm{Or}$, to determine the curve in terms of $\mathrm{R}$ and $\mathrm{P}$, we have

$$
\begin{aligned}
& \frac{\mathrm{R}}{\mathbf{P}}=\frac{r}{p} \ldots \ldots \ldots \ldots \ldots \ldots \ldots \ldots \ldots \ldots \ldots \\
& \mathbf{R}=2 \mathrm{P}
\end{aligned}
$$

From these last equations it will be easily seen that the involute to the caustic by reflexion, is in fact the curve which would be traced out by a point similarly situated with the radiating point in a curve similar and equal to the reflecting curve made to roll on its circumference, similar points having first been in contact, and both curves being in the same plane.

XLV. Reply to Mr. R. C. Taylor's Remarks on the Hypothesis of Mr. Robberds on the former Level of the German Ocean. By J. W. Robberds, Esq. Jun.

[Continued from p. 207.]

A FTER admitting the general validity of the evidence, which I have adduced from historical facts, and from the names of several places on the verge of these valleys, Mr. Taylor has objected to the accuracy of some minor points, which do not materially affect the main argument. I acknowledge readily the error into which I was betrayed, respecting Waybridge. As I could find no village bearing that name on either of the three rivers, I too incautiously adopted Gillingwater's version of it, who, in his History of Lowestoff, p. 27, rendered it Weybread, without even mentioning the real name given by Swinden. Mr. Taylor calls mine a "mistaken quotation." This is not correct ; for I quoted the word right, but explained it wrong, having cited it as "Waybridge (the present Weybread)." The bridge at Acle, so designated, may have existed in the eleventh century, without affording any conclusive proof of the fallacy of my inference from more general and unquestionable facts. I much wish that Mr. Taylor had given his authority for that statement. In the earliest account of the priory founded there in the reign of Edward I., 
it is described as St. Mary of Weyburgh*. But I will not hazard even a conjecture upon so insecure a foundation as the unsettled orthography of that period.

I cannot understand the grounds upon which Mr. Taylor objects to my etymology of Herringby and Herringfleet. His quotation from Domesday Book of Haringbei, is decidedly in favour of my opinion. The Anglo-Saxon for herring was hæpunz; and at this time it is in Dutch haring, in German häring, and in French hareng. The derivation is so obvious, that no other either has been, or can be, offered;-how then can it be said, that my explanation of it is strained, in order " to favour a given theory?" With respect to Herringfleet, the existing form of the name is a far better authority to ascertain its origin, than that which was employed by the Norman surveyors. Their register has but few instances of the same place having been twice entered precisely in the same manner; and the variations of the spelling are such, that nothing can be inferred from the introduction or omission of merely a single letter in any name. In cases of doubtful etymology therefore, truth must be sought after by comparing the ancient and modern appellations with those local or historical contingencies from which the designation was most probably taken. If we apply this rule to Herringfleet, we shall find, that the early entry of Herlyngfete proves nothing in opposition to that interpretation, which the present name so obviously suggests. There can be no doubt with respect to the meaning of the last syllable. It is evidently the AngloSaxon Fleot, the signification of which, according to Somner, was "Astuarium-an arme of the sea; a place where the sea ebbeth and floweth." Junius gives it the same meaning-" Sinus maris, BEstuarium." Under the Latinized form of Fleta or Fletum, Sir Henry Spelman explains it as "Astuarium, fluentum, seu canalis quem aqua fluens et refluens occupat;" which Dufresne, in his Gilossary, has confirmed, by repeating this passage verbatim after our Norfolk antiquary. Mr. Taylor's scepticism has made me particular in citing these authorities; for, after all, this syllable is the most important part of the name to which it belongs, and must decide its character. It denotes the situation of the place in question to have been upon an cestuary, or arm of the sea ; and this will be found to be invariably the case, in every instance in which the term occurs throughout our maritime districts + . This is the only material circumstance

* Blomefield and Parkins, 8vo. vol. ii. p. 92.

+ Fleet, at the mouth of the Arm, in Devonshire; Flect, near Portland Isle, in Dorsetshire; Northfleet and Southfleet, near Gravesend; Ebbsfeet, 
circumstance required to substantiate my theory; for whether the adjunct be Herlyng or Heryng, it cannot alter the fact that Herringfleet, in the Anglo-Saxon times, was situated upon an " æestuary or arm of the sea." This point being settled, the import of the prefixed term must be gathered from probability and consistency, while authority and fact are either silent or discordant. Which then is the most probable and consistent opinion-that a village, denominated in part from its situation on an arm of the sea, should have taken the rest of its name from a fish in which that sea abounds, or that it should have combined with such an appellation the name of another place, in a remote and inland part of the country, with which it does not appear ever to have had the slightest connection? To prefer the latter conclusion would indeed be to strain etymology, for the purpose of "favouring a given theory." With equal, if not with greater reason I might have alleged, that the principal canal in the town of Rotterdam is actually called the Haringylict; for it is surely more rational to suppose, that the fishermen, who inhabited Lothingland, kept up an intercourse with the shores of the opposite continent, than to believe, out of mere respect for the orthography of Domesday Book, that they travelled forty miles up the country, to borrow from Harling (a market town of Guiltcross, not Shropham, hundred) a name for one of their early settlements. Nor is Mr. Taylor more fortunate in his objection, that the names of Herringby and Herringfleet can have "no reference to fish, whose habits lead them to avoid shallow muddy rivers." This argument sets out with a most flagrant petitio principii-actually first assuming as a fact, the very point which is to be demonstrated. Let it be proved that, in the Anglo-Saxon times, there were no waters but " shallow muddy rivers" in these valleys, and I will then admit the force of the objection. Let it be proved, that Fleot denotes-not " an æstuary or arme of the sea,"-but "a shallow muddy river ;"-1hat the brine, which five centuries afterwards supplied the salt-pans at Herringby and Fritton, was conveyed to them by "shallow muddy rivers :"-I will then allow, that the etymology, which I have suggested, affords no collateral evidence in support of my argument. But until the proofs which I have required can be adduced, I must still believe, that Herringby and Herringfleet were fishing establishments of the early Saxon colo-

in the Isle of Thanet; Bemflect, in Essex, near the Isle of Canvey; Fleet, Surfleet, Wainfleet, and Saltfleet, on the coast of Lincolnshire;-all these places were evidently so denominated from the course of the tidal waters, on the banks of which they were fixed.

New Series. Vol. 2. No. 10. Oct. 1827. $2 \mathrm{~N}$ nist 
274. Mr. Robberds on the former Level of the German Ocean,

nists, and that they form a part of that commected chain of facts, which attests the former residence of the sea in these valleys, and illustrates the cause of its gradual retreat.

I have thus far restricted my observations to those points, on which Mr. Taylor has touched, within the range of historical evidence; there are some other comments of minor importance, which I have omitted to notice, thinking it unnecessary to show how far they are from having in the least degree invalidated my statements. I shall now proceed to the consideration of his remarks upon the earlier phrnomena which this district presents. Mr. 'Taylor's object is to make it appear, that these "belong to an antediluvian formation; and thercfore cannot be admitted as evidence of supposed changes or of events that have occurred subsequently to the deluge." Here again a favourite dogma of the modern geological school is advanced as certain and infallible. It is not necessary that I should stop now to explain the grounds of my dissent. In a future stage of this inquiry, I shall not shrink from avowing and defending my own opinions, or from pointing out the errors of those who, under the mistaken idea of serving the cause of religion, are so anxious to square the ceconomy of nature with the early traditions of the East and the imperfect philosophy of an ignorant age. The beds of sand and gravel, which Mr. Taylor's orthodox creed calls diluvium, belong of course to an older formation than the alluvial deposits of the valleys. I wish to avoid all idle disputes about mere words; and therefore admit at once, that if the upper layers of marine shells on the sides of the hills can be proved either to have preceded, or to be part of the former, instead of being, as I regard them, the first and earliest portion of the latter, they would in that case afford no evidence of the height to which the waters of the ancient æestuary once flowed. But I deny that $\mathrm{Mr}$. Taylor has adduced a single satisfactory proof in support of his position,- - that these shells belong to the $\mathrm{crag}$ stratum, or that early formation which he calls antediluvian. According to his hypothesis, as explained by his Section, No.3, a bed of crag, surmounted by diluvium, is uniformly spread over the chalk through the whole of this district; and the Valley of the Yare is an excavation produced by some powerful stream, which, by acting upon the upper beds after they were complete, intersected them in such a manner, as to display their series in the escarmment on either side. In opposition to this theory I have already shown,

First, that although the chalk rises on each side considerably above the surface of this valley; yet in no instance has it 
ever exhibited a natural cliff, or precipitous bank, capped with sand and gravel.

Secondly, that beds of recent shells, similar to those which lie on the sides of the hills, are constantly discovered below the alluvial mud in the bottom of the valley; and

Thirdly, that these shells do not universally cover the chalk, and in fact, that no continuous layer of them exists out of the basin of this valley, to prove that they have any connection with the Crag of Harwich, Woodbridge, Lowestoff, and Cromer.

According to Mr. Taylor, "experienced well-sinkers do affirm, that on forming deep wells in various places round Norwich, at a distance from the river, they have occasionally encountered a stratum of shells overlying the chalk;" and he refers to one instance of this on Musholt heath. In consequence of this statement, I have again examined all the chalkpits in this neighbourhood: and over an area of several miles in extent, where this universal sub-stratum has been laid open in a great variety of situations, I have not been able to meet with a single shell in the sand by which it is covered. I have investigated with particular care those at the foot of Mount Surrey and under St. Michael's hill, which are in the immediate visinity of the well alluded to by Mr. Taylor, and could not perceive in them the least trace of what is called the Crag stratum or of any shelly deposit whatever.

It is not my wish to express the slightest doubt of any facts, which Mr. Taylor describes from personal observation; I only dispute his inference from them. There may be-I have indeed admitted that there are-in this district beds of fossils of marine origin, belonging to the superficial coat of sand and gravel; but, wherever they occur, they can only be regarded as local and casual vestiges of that ancient ocean, which once flowed over the highest ground in these parts ; for I must insist, that the total absence of any such remains in all the chalk-pits, that are not within the circuit of the valley, proves most decidedly, that the supposed stratum is altogether an unestablished deduction from misconceived and unsound premises. Geologists have applied too hastily to the diversified and partial features of this upper formation, the principles by which they have traced the continuity of the lower rocks. The outcrop of solid masses at distant points may be sufficient to indicate the inclination of their beds and the direction in which they extend; and it is the habit of drawing these conclusions from such appearances, which has led to the prevalence of the false idea, that, because there are beds of shells in the cliff at 


\section{$276 \mathrm{Mr}$. Robberds on the former Level of the German Ocean,}

Harwich, and others in that of Cromer, therefore the shells in the interior valleys of Norfolk, between those two positions, must necessarily belong to them, and demonstrate the existence of a connected layer, concealed by beds of sand and gravel, through the whole intermediate space. Mr. Taylor has overlooked the influence of this habit; he has made no allowance for the disposition which it produces to generalize inferences, and to measure the effects of the most opposite properties in nature, by one pre-conceived system and uniform scale; he has surrendered his judgement to authority-has endeavoured to reconcile with the promulgated opinions of others, all that has come under his own observation; and has thus permitted himself to appeal to a few fossils, taken from a single well, as "absolute proof of a continuous shelly bed," although the actual series of the strata, laid open to day-light for the space of several hundred yards within a short distance of that very spot, exhibit not the faintest trace of any "continuous bed" of the kind. The authority on which Mr. Taylor seems principally to rely, is that of Mr. W. Smith, who has stated, that "through Norfolk the Crag shells lie near to, or are in contact with, the top of the chalk." But whence are the facts taken, on which this statement rests?-From the vale of Aylsham and the Flegg hundreds, which are portions of the ancient æstuary itself. Proofs of the general diffusion of marine exuvia through the whole extent of the valleys, multiply upon me daily; but from the higher grounds, whence alone the evidence of an universal and continuous Crag stratum could be drawn, nothing has yet been adduced, to support, in a satisfactory and decisive manner, the theory that has been advanced. On the contrary, wherever excavations have been made, that afford opportunities of exploring the nature of the masses of earth above the chalk, the non-existence of a connected shelly deposit has been actually and clearly ascertained. We have therefore no proof whatever, that the accumulations of shells within these valleys belong to the same æra and the same formation, as those which in some places are found so deeply buried beneath thick banks of sand and gravel. They may be-and many circumstances indicate that they certainly are-monuments of distinct natural operations, proceeding from separate causes, and occurring at various dates.

An attentive consideration of geological facts has led me to the conclusion, which, as I have since found, was also adopted by the unfortunate Lavoisier,-viz. that the series of stratified rocks and alluvial soils, which compose the surface of our globe, have been produced by alternate elevations and de- 
pressions of the sea. These changes I conceive to have been effected by successive transfers of the existing body of water from one hemisphere to the other; and the solution of the problem, which they exhibit, appears to be connected with some of the most interesting astronomical phænomena, displayed in the history of the heavens. I have been induced thus to anticipate the course of my inquiry, and to point out the nature of the general inferences which I shall hereafter draw from a long chain of evidence, in order to explain my view of the distinction between the Crag stratum and the shelly deposits of the Norfolk valleys. The chalk which constitutes so large and important a feature in the central basin of Europe, was formed in the bosom of a tranquil ocean, whose surface must have been more than 1000 feet above that of the sea, now existing in this quarter of the globe. Beneath the present level of those seas, we find the most decided traces of submerged forest-land, at points so distant from each other and over spaces so extensive, that the fact cannot possibly be accounted for by any subsidence or sinking of the ground on which these trees were produced. From the nature of their remains it is evident, that they can have flourished only on dry land; and as they grew in some of the lowest hollows of the chalk, it is equally clear, that the waters, in which that formation was consolidated, must have been withdrawn to such an extent as to leave uncovered considerable tracts, which at this time are constantly overflowed by the tides, During this retreat of the waters, their level appears to have been subject to repeated minor fluctuations, and the lower basins of the chalk were filled with beds of sand and clay, which in some districts exhibit the vestiges of fresh-water tribes, alternating with the marine exuviæ of an intermediate date. These beds seem scarcely to have extended into Norfolk, where the general range of the chalk was probably above their level; some portions of them may however rest in the deepest bottoms of the valleys, and on the declivities of the present coast; and it was perhaps on their surface that the forests arose and the animals lived, which a subsequent catastrophe overwhelmed*. At the period to which I am referring, there was no variety of climate over the whole face of our globe; the

* Mr. W. Smith, in his geological map of Norfolk, has indeed delineated Strumpshaw and Poringland hills, as detached outlying masses of the Lopdon blue clay; but I believe that Mr. Taylor will agree with me in regarding this as an error; for I am not aware that any organic remains have ever been found in these hills, to identify them with the formation to which $\mathrm{Mr}$. Smith considers them to belong. 
vegetable and animal tribes, which are at present never found beyond the tropical regions, abounded then even in the highest northern latitudes, for their vestiges have been discovered there under such circumstances, as prove them to have been natives of the districts in which they perished. Their remains are either buried under, or associated with beds of sand and gravel, which rise to between 300 and 400 feet above the present level of the sea, and from which it is manifest, that the waters must have again invaded these tracts, rising above the height at which these memorials of their action still exist. By this elevation of the ocean, the forests which had grown up during its retreat, were largely overwhelmed,-many of the land animals, which in the interval had taken possession of the woods and pastures of the earth, were destroyed by the ascending flood,and various deposits of marine bodies were mixed throughout the general mass of the detritus collected by the agitated waves. The earliest of these relics constitute what is commonly termed the Crag stratum; and in order "to favour a given theory," the name of Diluvium has been employed to designate the upper beds formed during the subsequent stages of this operation. From the nature and extent of the materials thus accumulated, it is clear that this last residence of the sea in these parts must have been of long duration; and it by no means follows, that the deposits of shells, which have been found intermingled with them, must necessarily be continuous and contemporary. The marked prevalence of particular genera at different points-their apparently gradual approximation towards a more perfect agreement with the testaceous tribes of the present day-their diversified characters and dissimilar positions, - all indicate, that these deposits must have been the unconnected results of those successive local changes which attended the access and departure of the waters.

Such is the course of events which I have traced in the geological records of this district. Mr. Taylor's theory and the doctrines of the school to which he belongs, in effect admit the outline of the series of operations here described; they allow that the ocean, in which the chalk was formed, had been withdrawn, and that this was followed by a rising and then by another falling of the waters; but instead of connecting the two last changes with the other natural revolutions manifested in the structure of our globe, they ascribe them to a transient, although universal inundation, effected by supernatural agency. It would be useless to seek explanations of physical difficulties from those who cut every knot by the aid of divine inter 
position. But I am unable to perceive how they can reconcile with their views of the question, the positive fact, that considerable portions of what was dry land before the last irruption of the waters, are at this time actually covered by the sea. This is proved by the submarine forests, that have been found on every coast of our island. . The lands on which they grew, must have been at that distant period far above the range of the waves; they must also have been submerged by that last catastrophe, which in the current phraseology of the day is called diluvian. It cannot then be denied, that before this event, there were sylvan tracts which are now buried beneath the floods; and if we compare those remains of them, which have been discovered on our own shores, with the corresponding traces that exist on the opposite coasts of the continent, it will be found by no means improbable, that they were originally connected, and that the whole bed of the intervening sea was at that time an extensive wooded valley.

From whatever cause then, this last great influx of waters over our quarter of the globe may have proceeded, it is admitted by all parties, that 'such an event did take place; neither can it be disputed, that in the course of their retreat to their present level, the last remaining portions of them, which left our district, must have flowed out through the valleys, which at this time open to the ocean. Consequently in the concluding stage of this revolution, there must have been a period, at which the retiring flood was confined within the limits of the valleys; or, in other words, when the valleys were arms of the sea or æestuaries. Here then is the point, at which the records of nature and the facts of history meet and coincide. Even the most conflicting theories acknowledge a certain series of changes, at the termination of which the eastern valleys of Norfolk must have been connected branches of an æstuary; it is also allowed on all sides, from the most positive and satisfactory evidence, that this was their actual condition within less than seven centuries. Are we then to believe, that these physical proofs and historical testimonies, while they agree in every essential particular of the point which they establish, still relate to two distinct facts and two separate periods? Is it not, on the contrary, more consistent with the harmony of nature, more agreeable to sound reason, more pertinent to an intelligible and unsophisticated philosaphy, to refer them to one and the same state of things? Geological phænomena inform us, that at some uncertain date, an æstuary must have occupied these valleys; History announces, that at a definite æra such an æstuary did exist. By connect- 
ing these circumstances, the only point which is left unsettled by the former, is decided by the latter, and the whole scheme becomes clear and uniform ; but by persisting in keeping them separate, we are bewildered in a maze of inexplicable mysticism, and embarrassed amidst a chaos of imaginary strata and supposititious diluvian remains. So also by pursuing these principles, the subsequent conversion of this æestuary into a range of solid and productive land, exhibits the continued advance of the same operation; its progress displays the result of the same immutable laws; it marks another stage in the same consistent and uninterrupted process; it connects the changes of all past times with the recent creations of the present day.

It is then very evident that during this revolution, the retreating waters must for a season have been confined within the circuit of the valleys; and whatever deposits were formed at that time, cannot of course extend beyond the same space. Hence, if we find deposits that are actually restricted within those limits, the legitimate inference is, that they belong to that period and were collected under the circumstances just described. I have already shown the total want of the necessary proofs, to identify or connect the shelly beds of the Norfolk valleys with any others on higher grounds, or in positions that indicate an earlier origin; it now therefore only remains for me to make it appear manifest, that they do terminate on the sides of the hills which skirt the valleys. This point is in fact substantially admitted by $\mathrm{Mr}$. 'Taylor ; for he allows that "the chalk rises above the level of the highest crag deposits;" that these deposits "rarely rise to 80 feet above the present level of the sea, and in general not more than half that elevation;" and that after tracing them in the valley of the Yare, "it is chiefly on descending again into the other valleys of this district, that fresh proofs present themselves." In considering these statements we must remember, that Mr. Taylor universally refers to the Crag stratum of other writers every layer of shells that comes under his own observation. If then we divest his accounts of the erroneous colouring given to them by this misconception, what terms can describe more explicitly the very facts to which I have appealed? They acknowledge that these beds of shells do not extend over the high grounds-that their general elevation is 40 feet above the level of the sea-and that they are confined to those valleys over which the ancient æstuary flowed. In more than one instance I have also ascertained the positive fact, that the upper stratum of these shells is nothing more than a narrow belt, superficially 
superficially reposing on the slope of the hills. At page 14 of my Observations, I referred to one bed, a section of which, being laid open, showed "that it gradually shelved off to a point as it receded from the valley, and soon terminated." Since that time it has been completely cut away by the chalkdiggers, and not a vestige of it is now left. In another pit I noticed two layers; the lowest not much above the surface of the chalk, consisting of broken shells, mixed in an indurated mass of gravel and ferruginous sand; and the upper about ten feet higher, composed principally of the Buccinum undatum* and Turbo littoreus loosely imbedded in a white quartzose sand. On my last visit to this spot I found the latter entirely exhausted for the space of about fifty yards, except a small portion not more than six inches deep and seven feet in length, which it was evident, that the next excavation would altogether remove. If to these decisive cases we add the striking fact, that no traces whatever of corresponding beds are discernible in any upland situations, where the strata have been actually explored, we have a right to infer from such circumstances, that these marine deposits are confined to the basins of the valleyst. It is far however from my object to contend, that they are all of the same age; I have on the contrary admitted, that the lowest are of a more ancient date, and appear to have some affinity to what is called the Crag stratum; it was from the upper and more recent beds that my conclusions were drawn. Not only is it evident that these are not buried beneath thick beds of sand and gravel; but we have the most decided proofs, that they actually repose on the surface of that mass which bears the name of dituvium. This I consider to be the essential characteristic of that subsequent adventitious formation, which has been with propriety termed alluvial; and every circumstance connected with these beds tends to corroborate this account of their origin. The uncompact and loose arrangement of their materials distinguishes them at once from the Crag, the structure of which, according to Mr. Taylor's description, is in some places so solid and rocklike, as to admit of its being hollowed into artificial caves and

*'The Murex striatus of Mr. Taylor.

†The "diluvial agency" by which Mr. Taylor imagines them to have been displaced from those situations, where, according to his theory, they ought to be found, is a most convenient assistant, whenever a stubborn unaccommodating difficulty is to be 'swept away, or a reason' assigned for' the absence of material evidence. I should be almost disposed to regret having rejected its services, did I not remember, that they would be of no avail, since that, which may be made to account for every thing, proves nothing.

Nero Series. Vol. 2. No. 10. Oct. 1827. 20 grottos, 
grottos, and even used for building. So also on the other hand, the exuviæ which they contain bear so perfect a resemblance to the littoral shells which now abound in the neighbouring ocean, that they may be regarded as necessary links in the series of marine spoils-connecting those which attest the last previous operations of the sea with those which are daily left on its present shores by the ebbing tide.

In the list which I gave of these shells, I did not pretend to enter into minute scientific details; I only enumerated those, which are sufficiently abundant to render probable the actual abode of the living animals, where their remains are still to be seen. Single specimens of rare or extinct tribes occupy the most conspicuous and important places in the cabinets of the curious and the transactions of learned societies; but they are of no account in determining the character and antiquity of any formation, in which they may have been accidentally associated with multitudes of the commonest and most recent species. The microscopic eye of science often dwells so intently upon trifles, that it magnifies them into undue consequence; and their proportions thus unnaturally enlarged, engross the whole field of view, excluding all the ordinary facts and constantly recurring phænomena, from which alone just and comprehensive ideas of physical truths can be derived. Hence it is that a few extraneous substances, dislodged from an earlier stratum, and fortuitously washed down to the side of the valley of the Yare, are triumphantly appealed to in support of a theory, which is not in accordance with all the prevailing and most decidedly marked features of the district. The tooth of a Mastodon has been discovered atWhitlingham! Prodigious! This wonderful grinder therefore is an "absolute proof" that all the myriads upon myriads of Buccina, Tellina, Cardia, Mytili, Turbines littorei, \&c. whose exuviæ line: the basin of this valley, were coeval with the Mastodon, the Palæotherium, and all the lost races of quadrupeds, which perished in the last great convulsion experienced by the earth. It is far from my wish to treat with levity or ridicule the industrious researches of scientific men; but who can always suppress the rising smile at their complacent self-delusions, or never demonstrate, but with composed gravity, the haud sequitur of their inconelusive reasonings upon petty and misplaced facts? Nor would I be thought to under-rate the importance, either of our national, or of our provincial museums :- to those who use them intelligently and carefully, they are funds of valuable information; but I cannot too earnestly point out the necessity for great prudence in selecting, and still greater 
caution in drawing conclusions from the specimens exhibited in them. None are more easily imposed upon than the virtuoso;-none look at Nature with a more contracted ken than the mere student of curiosities. Let us for instance suppose, that Mr. Taylor had presented to one of these repositories of wonders a nicely fractured stone, neatly labelled "Granite, from the Black Meg Rock, near Beeston, on the coast of Norfolk." Some traveller in search of the scientific, espies this amongst the other treasures of the geognostically stored glass-case, and enters a minute description of it in his note-book. At the next conversazione he details to his listening coterie the newly discovered fact, that mountains of granite exist in Norfolk, and silences every sceptical inquiry, by appealing to this publicly displayed portion of Black Meg as an "absolute proof" of his assertion. I should wish to be informed how such an inference would be more rash, more unfounded, more preposterous, than the assumption, that the recent shells of the Norwich Valley must belong to the Crag stratum, because "the British Museum contains the tooth of a Mastodon," which was found there, and because a few other "travelled fragments" of a more ancient bed may perchance be dispersed amongst them. In the one instance Mr. Taylorimmediately perceives that all the boulders and pebbles of primitive rocks, which lie on the shores of Norfolk, were brought from a distance by powerful currents :-let him view the interior of our valleys with the same good sense, unswayed by authority and unwarped by prejudice; he will then admit, that no sound notions with respect to their general character can be obtained from those stray scraps of earlier remains-those rare morsels of antiquity - to which, as far as regards this question, a too ardent enthusiasm has given an imaginary and deceptive weight.

I am not so vain as to expect that I can shake Mr. Taylor's faith, or that of any advocates of the Diluvian theory. I know how tenacious our nature is of the creed which has once been embraced, and how difficult it is to erase from the mind impressions once received. But I have so far confidence in the truth of my opinions, as to believe that they will in time make their way, where they have not to contend with the inveterate influence of a pre-adopted system; and it is in this hope, that I have ventured upon the present reply to my opponents. Those alone can enter upon this inquiry with an unbiassed judgement, who are yet free to decide upon the general questions with which it is connected; and to such I feel assured that I shall not address myself in vain. Let them first consider well the arguments employed to prove the "antedilu$2 \mathrm{O}_{2}$ vian" 


\section{Mr. Robberds on the former Level of the German Ocean,}

vian". origin of the marine deposits in the Norfolk valleys. I will not ask whether these amount to a positive and irrefutable demonstration of the fact-it would be too much to require,-but do they afford any admissible even presumptive evidence in support of the peremptory conclusion that has been drawn? They have utterly failed in their attempts to establish a continuity of position and identity of character between these beds and any antecedent formation; and unless these two points can be clearly substantiated, all the rest is mere fable and conjecture.

On the other hand, let them observe the connection and harmony of the following train of inferences, deduced from the general phænomena of this district.

1. The masses of sand and gravel, here universally covering the chalk, denote by their elevation that the waters which formed them were raised between 300 and 400 feet above the range which the ocean now takes.

2. In the last stage of the retreat of these waters to their present level, they must have been drawn off through the valleys which open to the sea; and consequently there must have been a period, during which their streams entirely filled, and were confined to, these channels.

3. These valleys contain extensive beds of marine shells, which are not only spread over the bottom of them, but also at various points rise on each side to the height of about forty feet above the intervening alluvial formation. They terminate on the edge of the valleys, the uppermost of them resting on the surface of the sand, with a thin coat of vegetable earth above them, and consisting almost exclusively of the recent species which now inhabit the shores of the German Ocean.

4. At the earliest dawn of history upon this region, its valleys formed a connected astuary; we have positive evidence, that at the close of the eleventh century the salt tides still covered a considerable portion of them, and from that time they have been gradually converted into pasture land.

In this series, the place of the marine remains (at least of the highest of them) is so distinctly pointed out and clearly determined, that it seems almost impossible to entertain a doubt upon the subject. They must have been deposited after the banks of gravel and sand were completed; for they rest upon them.

They must have been formed at that period, when the waters occupied only the troughs of the valloys; for they are confined within the same limits.

They must have been left by the retreat of those waters to their present level; for they are the latest relics of the sea: and 
They prove the immediate connection between their native floods and the German Ocean, by their own close resemblance to the shelly tribes that now frequent the shores of the latter.

The successive stages of this revolution are here brought down by the records of nature to the period, from which historical documents attest its further progress. The change which is so incontrovertibly established by the latter, is at this point combined with, and, if I may so express myself, dovetailed into the operations displayed by the former; there is no break in the train of events-no suspension of the laws which regulate the material universe-no interruption of the eunomy of creation; but every link in the chain of evidence is so well adapted and so firmly riveted, that if $\mathrm{Mr}$. Taylor could even succeed in identifying these remains with those of the Crag pits of Suffolk and the Cliffs of Cromer, he would demonstrate, not the fallacy of my conclusions with respect to the eastern valleys of Norfolk, but his own error in assigning to that stratum so high and obscure an antiquity. The littoral character of these shells, the drifted substances intermingled with them, and the arrangement of the whole in parallel lines on both sides of what is admitted to have been once an æstuary, - these circumstances all support my conclusion, that there formerly existed at this elevation a beach or strand, and consequently, that the sea was there stationary for a considerable space of time during its retreat. This opinion is powerfully confirmed by numerous coincident traces of the same fact, not only in various situations on the shores of our own island, but also in distant countries. I purposely abstain from pointing them out now, as I am engaged in preparing for the press a detailed account of them, with geological and historical observations on the change of level that has taken place in different seas. When the facts which $I$ have collected in reference to this question are brought properly to bear upon it,-when it is seen that similar deposits of recent shells have been found in the beds and on the sides of other valleys, where no Crag stratum has ever been thought to exist, and even on the face of the oldest primitive rocks,-it may perhaps excite some surprise that so manifest and undeniable a truth should ever have been doubted. The stigma of heresy, which now attaches to my opinions, will, as I confidently anticipate, be then successfully wiped off; and it will be found that I have not been amusing the public with a fanciful and untenable proposition, but that I have been laying the corner-stone of a solid basis for future and more extended inquiry. 